\title{
Assessment of heavy metal concentration in vegetables grown within fungicide treated Cocoa plantations in Akamkpa Local Government Area, Cross River State, Nigeria and implications to human health
}

\author{
F. E. Ekpo \\ Department of Biological Sciences, Akwa Ibom State University, Ikot Akpaden, Mkpat Enin, P. M. B. 1167, Uyo, Akwa \\ Ibom State, Nigeria. Email: frikpo9@yahoo.com.
}

Copyright @ 2017 Ekpo. This article remains permanently open access under the terms of the Creative Commons Attribution License 4.0, which permits unrestricted use, distribution, and reproduction in any medium, provided the original work is properly cited.

Received 6th April, 2017; Accepted 1st May, 2017

\begin{abstract}
The study was carried out to investigate the concentrations of heavy metals in soil samples and edible vegetables (Heinsia crinita and Gnetum africana) grown within fungicide treated cocoa plantation in Akamkpa communities of Cross River State Nigeria. In each sampling community, the edible vegetables and soil samples were collected for the period of three months (March to May) and were replicated three times. The levels of heavy metals in soil and edible vegetable samples collected were determined using Atomic Absorption Spectrophotometer. The concentrations of heavy metals in soil samples collected from fungicide treated coca plantations were higher than those recorded in the control location in all the sample locations. The concentrations of heavy metals in edible vegetables (Heinsia crinita and Gnetum africana) collected from fungicide treated cocoa plantations exceeded the maximum permissible limits values of heavy metals for edible vegetables. The soils and edible vegetables (Heinsia crinita and Gnetum africana) in the fungicide treated cocoa plantations in Akamkpa communities are contaminated by heavy metals and may pose serious adverse health effect to the consumers and the ecosystem.
\end{abstract}

Key words: Akamkpa communities, edible vegetables, fungicide treated Cocoa plantation, heavy metals.

\section{INTRODUCTION}

The use of chemical pesticides in cocoa plantations in Nigeria has seen a sharp increase in recent years. Farmers in Akamkpa Local Government Area of Cross River State use chemical pesticides as a preventive and control measures against the possibility of devastating crops loss from pests and diseases and also to increase its yield. Chemical pesticides have been employed in cocoa plantations to control and eradicate pests and diseases and also to improve the yield of the crops in the area for several decades. However, there has been a rapid increase in the quantity and use of pesticides in cocoa plantations over the past two decades (Hodgson, 2003). The use of chemicals pesticides to control fungal diseases of cocoa has already caused grave damage to the soil, vegetables, water resources and the entire ecosystem, resulting in the health risk (Alloway, 1995).
Pesticides are widely used in cocoa plantations in Akamkpa Local Government Area probably due to the farmers' perception of insects and diseases control. This is because it is profitable, and no better alternatives measures are available, then spraying of pesticide is a good investment in the area (George, 2006). Pesticides are synthetic chemicals that are purposely applied to the environment with aim to suppress diseases and pests of plant and animal and also to improve their output.

Although, there is an increasing demand for cocoa beans (Taylor, 2000), pests and diseases pose a major challenge to its production (Bowers et al., 2001). Phytophthora pod rot (black pod) is the most prevalent disease of cocoa in Akamkpa Local Government Area (Isong, 2007). The disease is caused by Phytophthora palmivora and Phytophthora megakarya. The control of 
black pod disease is a major challenge for world cocoa cultivation. According to Tan and Tan (1990), several methods have been adopted by researchers and farmers to control Phytophthora pod rot of cocoa. The most common is the routine use of fungicides to supplement good farm management practices. Among the different types pesticides known, coper based fungicides are extensively used by farmers, because of their cost effectiveness and their broad spectrum activity. According to Bempah et al., (2011), copper based fungicide is toxic, persistent nature, and the residual effect in the crops grown is detrimental to health. Repetitive applications (6 to 9 sprays/year) of copperbased fungicides in cocoa plantation bring serious risks to human health and an adverse effect on the sustainability of the agro-ecosystem.

Juraske et al. (2001) observed that exposure to pesticide residues through the diet is assumed to be five times higher than exposure routes of air and water in magnitude. According to the World Health Organization (WHO, 2001), food consumption consists an average of $30 \%$ (Based on mass) of fruit and vegetables, and vegetables are the most frequently consumed. Since vegetables are mainly consumed raw or semi-processed, it is expected that they contain higher pesticides residue levels. Given the potential risk of pesticides for public health, the use of pesticides to control cocoa diseases in cocoa plantations in farming communities of Akamkpa Local Government Area is of great concern to the consumers because of its health implication. Although, pesticide residues in foodstuffs have been carried out for decades in most developed countries (Claeys et al., 2011). However, edible vegetables grown within fungicide treated cocoa plantations in Akamkpa Local Government Area are not much investigated from pesticide contamination point of view. Everyday, people are being encouraged by physicians to consume more vegetables for their health benefit. Therefore, the objective of this study was to assess the concentration of heavy metals in edible vegetables grown within fungicide treated cocoa plantations in two communities of Akamkpa Local Government Area of Cross River State and to create awareness on the effects of heavy metals on human beings and the environment and the potential health risks associated with the pesticide residue with regard to consumers.

\section{MATERIALS AND METHODS}

\section{Study area}

The study was conducted in two cocoa plantations in Akamkpa Local Government Area of Cross River State Nigeria. The cocoa plantations were located at Old Ndepiji community and Owon community. In each of this community, there is a cocoa plantation that was established in early 1980 s by the community. Cocoa (Theobroma cacao L.) is a major cash crop cultivated in these communities and it is a source of livelihood to the farmers. The dominant cultural practice of cocoa plantation in these communities involves planting of the cocoa trees on forestlands with various indigenous food crops, vegetables, fruit trees and medicinal species that has economic importance to the farmers and also provide shade for the cocoa plants. In these communities, the popularly eaten food is mainly carbohydrate. Indigenous vegetables play useful role in producing food quality like proteins, minerals, vitamins and fats. Farmers in these communities depend on indigenous vegetables grown in the cocoa plantations. Cocoa play a significant role in the lives of the rural economy in the area, as the industry is dominated by large numbers of smallholder peasant farmers who depend on the cocoa for their sustenance. Cocoa plant, like all living organisms are attacked by a wide range of pests and diseases. When this happens expected production targets by the farmers are not met, their economies and livelihood are adversely affected. A preventive and curative measure which is the application of chemical pesticides, mostly coper based fungicides are therefore necessary in the cocoa plantations to control pests and diseases and to increase the yield (Adeyeye and Balah, 2007). Indigenous vegetable and fruit crops such as Heinsia crinita, Gnetum Africana, Lasienthera Africana, Mangifera indica are grown within cocoa plantation for consumption and to provide income to the farmers. These vegetables are consumed on daily basis. They are cooked in almost all the hotels, restaurants and bars in these communities. These indigenous vegetables are also importance dishes in all traditional feasts or parties (naming ceremony, birth day party, traditional marriage, wedding ceremony and burial ceremony) in the communities. Each year, chemical pesticides mostly copper based fungicides are sprayed in cocoa plantations where these indigenous vegetables and fruit crops are grown together with the cocoa trees. According to Ukpong (2010) chemical pesticides are sprayed in cocoa plantations for about 6 to 9 times of high doses in a year depending on the variation of rainfall pattern to control or reduce the impact of pests and diseases in their farms. Realizing the wide usage of these indigenous vegetables (Heinsia crinita, and Gnetum africana) in the studied communities, it become necessary to ascertain the concentrations of heavy metals in these vegetables and the effect to the well-being of the consumers.

\section{Materials}

Samples of soil and leaves of Heinsia crinita, (Atama) and Gnetum Africana (Afang) were collected from treated cocoa plantations in the two different communities (Old Ndepiji and Owon) in Akamkpa Local Government Area of Cross River State and the control location was a bush 
Table 1. The mean Concentrations $\left(\mathrm{mgkg}^{-1}\right)$ of heavy metals in soils from Fungicide treated cocoa plantations in Communities of Akamkpa L. G Area, Cross River, Nigeria State.

\begin{tabular}{lccc}
\hline Heavy metals & Old Ndepiji Community & Owon Community & Mfanosing Community \\
\hline $\mathrm{Fe}\left(\mathrm{mgkg}^{-1}\right)$ & $5.17 \pm 0.28$ & $5.22 \pm 0.05$ & $3.05 \pm 0.01$ \\
$\mathrm{Zn}\left(\mathrm{mgkg}^{-1}\right)$ & $4.30 \pm 0.15$ & $4.60 \pm 0.02$ & $2.45 \pm 0.10$ \\
$\mathrm{Cu}\left(\mathrm{mgkg}^{-1}\right)$ & $7.28 \pm 0.15$ & $7.22 \pm 0.20$ & $2.01 \pm 0.05$ \\
$\mathrm{~Pb}\left(\mathrm{mgkg}^{-1}\right)$ & $2.95 \pm 0.02$ & $2.68 \pm 0.05$ & $0.05 \pm 0.10$ \\
$\mathrm{Cr}\left(\mathrm{mgkg}^{-1}\right)$ & $3.35 \pm 0.05$ & $3.45 \pm 0.20$ & $1.02 \pm 0.01$ \\
$\mathrm{Cd}\left(\mathrm{mgkg}^{-1}\right)$ & $2.01 \pm 0.01$ & $2.10 \pm 0.05$ & $0.01 \pm 0.02$ \\
$\mathrm{Ni}\left(\mathrm{mgkg}^{-1}\right)$ & $4.25 \pm 0.15$ & $3.75 \pm 0.25$ & $0.10 \pm 0.30$ \\
\hline
\end{tabular}

fallow at Mfanosing where there is no cocoa plantation for the period of three months (March to May). In each of the community, samples of soil and leaf of (Heinsia crinite and Gnetum africana) were collected from fungicide cocoa plantations and untreated pesticides bush fallow at Mfamosing (control) location. Samples of soils and leaves were taken from three different places in each of the studied community and this was done by a random process from the field. The collected samples were sealed and labeled with a unique sample identity and taken to Central Research Laboratory, Akwa Ibom State Ministry of Science and Technology for heavy metals analysis.

\section{Methods}

\section{Preparation and preservation}

Samples of leaf Heinsia crinita (Atama) and Gnetum africana (Afang) were washed in fresh running water to eliminate dust, dirt, possible parasites and then were again washed with deionized water. The clean leaves samples were air-dried and placed in an electric oven at $65^{\circ} \mathrm{C}$ for 48 hours. The dry leaves samples were homogenized by grinding using a ceramic coated grinder and used for metal analysis. All soil samples were spread on plastic trays and allowed to dry at ambient temperature for 8 days. The soil samples after drying were ground with a ceramic coated grinder and sieved through a nylon sieve. The final samples were kept in labeled polyethene containers at ambient temperature before analysis.

\section{Digestion and determination}

Five (5) grams of leaves samples were weighed into $50 \mathrm{ml}$ beakers, followed by the addition of $20 \mathrm{ml}$ mixture of analytical grade acids $\mathrm{HNO}_{3}: \mathrm{HClO}_{4}$ in the ratio $5: 1$. The digestion was performed at a temperature of about $150^{\circ} \mathrm{C}$ for 2 hours. After cooling, the solution was made up to a final volume $(50 \mathrm{ml})$ with distilled water. The metal concentrations were determined by atomic absorption spectrometry using a Unicam Model 299 Atomic Absorption Spectrophotometer (AAS). Analysis of each sample was carried out three times to obtain representative results and the data reported in $\mathrm{mg} / \mathrm{kg}$ (on a dry weight basis).

\section{Data analysis}

Data were generated in triplicates and expressed as mean ( \pm ) standard deviation and was determined according to the method of Steel and Torrie (1980). Significant differences were determined by the LSD (probability level of 0.05 was considered statistically significant).

\section{RESULTS}

The mean values of heavy metals Copper $(\mathrm{Cu})$, Lead $(\mathrm{Pb})$, Zinc ( $\mathrm{Zn}$ ), Iron ( $\mathrm{Fe})$, Cadmium (Cd), Chromium ( $\mathrm{Cr}$ ) and Nickle ( $\mathrm{Ni}$ ) contents of soil samples obtained from two cocoa plantations (Old Ndepiji and Owon) and the control at Mfanosing is shown in Table 1. The level of heavy metals contents observed from the soil samples in Old Ndepiji and Owon cocoa plantations were significantly higher than those recorded from the control location. The mean values of heavy metals contents obtained from plant samples (Heinsia crinite and Gnetum africana) in two cocoa plantations and the control location is shown in Table 2. The mean values of heavy metals contents obtained from the plants samples in Old Ndepiji and Owon cocoa plantations were significantly higher than those obtained from the control location. Several studies have shown that plants grown in heavy metals polluted soils have higher concentrations of heavy metals than those grown in unpolluted soils (Gutormsen et al., 1995; Kabata-Pendias and Pendias, 1992).

The mean values of $\mathrm{Cu}$ obtained from soil samples in two fungicide treated cocoa plantations communities (Old Ndipiji and Owon) were $7.28 \pm 0.28 \mathrm{mg} / \mathrm{kg}$ and $7.22 \pm 0.05$ $\mathrm{mg} / \mathrm{kg}$ respectively. While the mean values Cu recorded 
Table 2. The mean Concentrations $\left(\mathrm{mgkg}^{-1}\right)$ of heavy metals in edible vegetables from Fungicide cocoa plantations in Communities of Akamkpa L. G Area, Cross River State, Nigeria.

\begin{tabular}{llccc}
\hline Heavy metals & Vegetables & Old Ndepiji Community & Owon Community & Mfanosing Community \\
\hline \multirow{2}{*}{$\mathrm{Fe}$} & Heinsia crinita & $13.02 \pm 0.02$ & $12.19 \pm 0.15$ & $5.25 \pm 0.10$ \\
& Gnetum africana & $11.05 \pm 0.10$ & $12.05 \pm 0.00$ & $4.90 \pm 0.05$ \\
$\mathrm{Zn}$ & Heinsia crinita & $11.54 \pm 0.05$ & $13.15 \pm 0.12$ & $5.66 \pm 0.10$ \\
& Gnetum africana & $12.01 \pm 0.01$ & $12.98 \pm 0.10$ & $5.00 \pm 0.20$ \\
$\mathrm{Cu}$ & Heinsia crinita & $12.05 \pm 0.01$ & $12.15 \pm 0.01$ & $2.14 \pm 0.11$ \\
& Gnetum africana & $12.15 \pm 0.02$ & $12.50 \pm 0.15$ & $2.09 \pm 0.05$ \\
$\mathrm{~Pb}$ & Heinsia crinita & $3.75 \pm 0.05$ & $5.78 \pm 0.20$ & $1.04 \pm 0.25$ \\
& Gnetum africana & $3.01 \pm 0.10$ & $6.25 \pm 0.01$ & $0.98 \pm 0.15$ \\
$\mathrm{Cr}$ & Heinsia crinita & $4.75 \pm 0.10$ & $5.16 \pm 0.10$ & $0.55 \pm 0.10$ \\
& Gnetum africana & $5.50 \pm 0.05$ & $5.35 \pm 0.01$ & $0.75 \pm 0.30$ \\
$\mathrm{Cd}$ & Heinsia crinita & $2.95 \pm 0.15$ & $4.35 \pm 0.70$ & $1.05 \pm 0.10$ \\
& Gnetum africana & $2.55 \pm 0.11$ & $4.65 \pm 0.50$ & $1.01 \pm 0.05$ \\
$\mathrm{Ni}$ & Heinsia crinita & $7.11 \pm 0.02$ & $7.21 \pm 0.02$ & $0.95 \pm 0.00$ \\
& Gnetum africana & $8.05 \pm 0.10$ & $7.03 \pm 0.10$ & $1.05 \pm 0.10$ \\
\hline
\end{tabular}

at control location (Mfamosing) was $2.05 \pm 0.01 \mathrm{mg} / \mathrm{kg}$. The mean values of $\mathrm{Fe}$ and $\mathrm{Zn}$ contents obtained from soil samples in Old Ndepiji were $5.17 \pm 0.10 \mathrm{mg} / \mathrm{kg}$ and $4.30 \pm 0.15 \mathrm{mg} / \mathrm{kg}$ respectively. The mean values of $\mathrm{Fe}$ and $\mathrm{Zn}$ recorded in soil samples obtained from Owon cocoa plantations were $5.20 \pm 0.25 \mathrm{mg} / \mathrm{kg}$ and $4.25 \pm 0.01$ $\mathrm{mg} / \mathrm{kg}$ respectively. While in Mfamosing (control location) the mean values of $\mathrm{Fe}$ and $\mathrm{Zn}$ in the soil samples were $3.12 \pm 0.01 \mathrm{mg} / \mathrm{kg}$ and $2.45 \pm 0.05 \mathrm{mg} / \mathrm{kg}$ respectively. The concentrations of $\mathrm{Pb}$ and $\mathrm{Cd}$ recorded from soil obtained in Old Ndipiji cocoa plantation were $2.99 \pm 0.05 \mathrm{mg} / \mathrm{kg}$ and $2.01 \pm 0.01 \mathrm{mg} / \mathrm{kg}$ respectively. In Owon cocoa plantation the concentrations of $\mathrm{Pb}$ and $\mathrm{Cd}$ were $2.68 \pm 0.02$ and $2.10 \pm 0.10$ respectively. While in Mfamosing (Control location) the mean values of $\mathrm{Pb}$ and $\mathrm{Cd}$ were $0.05 \pm 0.01$ and $0.01 \pm 0.01$ respectively. Similar trend of $\mathrm{Ni}$ and $\mathrm{Cr}$ contents were recorded in soil samples obtained from the two different cocoa plantations and the control location at Mfamosing. The higher concentrations of heavy metals recorded in the soil samples obtained from two fungicide treated cocoa plantations in the study communities could be attributed to chemical pesticides sprayed to control the black pods disease of cocoa in the plantations which the chemical pesticides contained a high level of these metals. Soil samples obtained from control location (Mfamosing) had reduced heavy metals contents because the area is not affected with these pesticides.

The two indigenous vegetables (Heinsia crinite and Gnetum africana) collected from two fungicide treated cocoa plantations, regardless of locations recorded a higher concentrations of heavy metals in the plant samples. The mean values of $\mathrm{Cu}$ contents in plants samples (Heinsia crinite and Gnetum africana) obtained from Old Ndepiji were $12.05 \pm 0.01 \mathrm{mg} / \mathrm{kg}$ and $12.15 \pm 0.02$ $\mathrm{mg} / \mathrm{kg}$ respectively. In Owon cocoa plantation, the concentrations of $\mathrm{Cu}$ in plant samples (Heinsia crinite and Gnetum africana) were $12.15 \pm 0.01 \mathrm{mg} / \mathrm{kg}, 12.00 \pm 0.00$ $\mathrm{mg} / \mathrm{kg}$ respectively. While at the Mfamosing, control location the concentration of $\mathrm{Cu}$ in the indigenous vegetables (Heinsia crinite and Gnetum africana) were $2.14 \pm 0.11 \mathrm{mg} / \mathrm{kg}, 2.09 \pm 0.05 \mathrm{mg} / \mathrm{kg}$ respectively. The mean values of Fe contents obtained from the indigenous vegetables (Heinsia crinite and Gnetum africana) in Old Ndepiji cocoa plantations were $13.02 \pm 0.02 \mathrm{mg} / \mathrm{kg}$ and $11.05 \pm 0.10 \mathrm{mg} / \mathrm{kg}$ respectively. In Owon community, the mean values of $\mathrm{Fe}$ contents recorded from (Heinsia crinite and Gnetum africana) were $12.19 \pm 0.15 \mathrm{mg} / \mathrm{kg}$ and $12.02 \pm 0.00 \mathrm{mg} / \mathrm{kg}$ respectively. While at Mfamosing, control location the concentration of Fe obtained from the plant samples (Heinsia crinite and Gnetum africana) were $5.25 \pm 0.10 \mathrm{mg} / \mathrm{kg}$ and $4.95 \pm 0.05 \mathrm{mg} / \mathrm{kg}$ respectively. The Concentrations of $\mathrm{Pb}$ and $\mathrm{Cd}$ contents observed in plant samples (Heinsia crinite and Gnetum africana) collected from Old Ndepiji cocoa plantations were $(3.75 \pm 0.05$ and $3.01 \pm 0.01), \quad(2.90 \pm 0.15$ and $2.15 \pm 0.02) \quad \mathrm{mg} / \mathrm{kg}$ respectively. Similar trend of $\mathrm{Pb}$ and $\mathrm{Cd}$ contents were recorded in plant samples (Heinsia crinite and Gnetum africana) obtained from Owon cocoa plantations. While at Mfamosing (control location) the mean values of $\mathrm{Pb}$ and $\mathrm{Cd}$ observed in the plant samples (Heinsia crinite and Gnetum africana) were (1.04 \pm 0.05 and $0.51 \pm 0.15)$, $(1.02 \pm 0.03$ and $0.98 \pm 0.10) \mathrm{mg} / \mathrm{kg}$ respectively. The low values of heavy metals observed in plant samples collected at Mfamosing bush fallow (control site) may be attributed to the fact that the area is free from chemical pesticides. The mean values of $\mathrm{Ni}$ contents recorded in indigenous vegetables (Heinsia crinite and Gnetum africana) obtained from Old Ndepiji and Owon community cocoa plantations were $(7.11 \pm 0.02,8.05 \pm 0.10)$ and $(7.21 \pm 0.02,7.05 \pm 0.10) \mathrm{mg} / \mathrm{kg}$ respectively. In Mfamosing, 
the mean values of $\mathrm{Ni}$ recorded in (Heinsia crinite and Gnetum africana) were $(1.75 \pm 0.25$ and $1.20 \pm 0.10) \mathrm{mg} / \mathrm{kg}$ respectively. However, the high concentrations of heavy metals recorded in the indigenous vegetables collected from the two cocoa plantations may be due to bioaccumulation of these metals in the plant tissues.

\section{DISCUSSION}

The concentrations of the heavy metals observed in soils obtained from fungicide treated cocoa plantations in the communities of Akamkpa Local government Area of Cross River state, Nigeria were higher than the concentrations of heavy metals observed in soil samples from Mfanosing bush fallow (control location). The higher concentrations of heavy metals recorded in the soil samples collected from fungicide treated cocoa plantations may be due to the frequent applications of chemical pesticides to control the diseases of cocoa and to increase its yield in the plantations. The result was in line with the work of (Nzegbule, 2007) who reported the higher concentration of heavy metals in soil obtained from pesticides treated cocoa plantations in Umuahia, Abia State of Nigeria. The soil samples obtained from fungicide treated cocoa plantations in the two communities (Old Ndepiji and Owon) showed a significant increased $(p<0.05)$ for all the metals analyzed. The result obtained from the analysis showed that the soil and vegetables obtained from the fungicide treated cocoa plantation were higher than those obtained from the control location. The lower values of heavy metals observed at the control site (Mfamosing bush fallow) in the soil samples may also be attributed to the fact that the area is free from chemical pesticides application. Since the area does not engage in cocoa plantation practice. The concentrations of the heavy metals in the soil samples obtained from the fungicide treated cocoa plantations communities were higher than the FEPA (1991) and WHO (2001) permissible limits. While the concentrations of heavy metals recorded in the soil samples obtained from the Mfamosing bush fallow (control location) were within the permissible limits. This implies that the soil samples obtained from fungicide treated cocoa plantations in Akamkpa Local Government Area of Cross River State are contaminated with heavy metals and pose serious environmental and health risk to the rural farmers.

The edible vegetables (Heinsia crinite and Gnetum africana) obtained from fungicide treated cocoa plantations communities of Akamkpa Local Government Area recorded the highest concentrations of heavy metals. The concentrations of the metals in edible vegetables obtained from fungicide treated cocoa plantations were higher than those obtained from the control location (Mfamosing bush fallow). The result was in line with the work of Ekpo et al. (2014) who reported the bioavailability of heavy metals in chemical polluted environment. The bioavailability of heavy metals recorded in edible vegetables obtained from fungicide treated cocoa plantation may be attributed to the frequent applications of this pesticide to increase the yield of cocoa and also to control the black pods of cocoa caused by a fungus (Phytophthora palmivora) in the cocoa plantations.

The situation is increasingly becoming a concern to the rural farmers in cocoa producing communities in Akamkpa Local Government Area of Cross River State as the business expanding and pesticides applications are carried out without any control measures.

The results obtained from laboratory analysis indicate that soils and edible vegetables obtained from fungicide treated cocoa plantations communities in Akamkpa Local Government Area are contaminated with heavy metals.

Scientists have reported that heavy metals encouraged tumor and mutations at greater amounts in animals and they have capacity of producing genetic harm to germ cells of both male and female animals (Hayes, 2004). Wagner (2003) reported that heavy metals are growing toxins which through biomagnifications and bioaccumulations in plants affect the health of humans. Heavy metals are extremely poisonous at comparatively smaller amount in animal including human beings. Ingesting food or drinking water with very greater degree of heavy metals relentlessly infuriates the stomach results in diarrhea and vomiting (Hayes, 2004). Dudka and Miller (2009) reported ways for the connection of heavy metals to the human body comprises direct breathing of polluted air, drinking of polluted water and direct contact with soil and ingestion of food comprising of plants grown in metal-polluted soil.

Heavy metal-polluted food can severely reduce some vital nutrients in the body that are accountable for declining immunological defenses, growth delay, reduced psychosocial abilities, and increases greater occurrence of upper gastrointestinal cancer degrees (Arora and Musa, 2008).

More et al. (2003) reported that heavy metals are nonbiodegradables and they are recognized as environmental contaminants causing cytotoxic, mutagenic and cancerous (carcinogenic) effects in animals. The biotic half-lives of these heavy metals are lengthy and furthermore they have capacity to store in various organs of the body and therefore causing health problems in human. Continuous exposure of heavy metals in soil and edible vegetables may lead to the accumulation of these heavy metals in kidneys, causes kidney diseases, lung disorders like bronchiolitis, emphysema and alveolitis (Smith, 2010). Heavy metals are also known for its toxicity and negative impacts on human health. Absorption of swallowed heavy metals may have a severe danger to public health. Some long lasting negative impacts of Lead toxicity includes colic, constipation and anemia (blood related disorder) (Bolger 
et al., 2000).

Although, a number of heavy metals are essential for biological systems, it's become toxic when their concentration level exceeds those required for correct nutrition. According to Walter et al. (2005), metals toxicity occurs when an organisms is unable to cope with additional metal concentration by direct usage, storage and excretion.

\section{Conclusion}

The concentrations of heavy metals recorded in edible vegetable obtained from fungicide treated cocoa plantations in Akamkpa Local Government Area of Cross River State, Nigeria were higher than the FEPA and WHO permissible limits. Therefore, edible vegetables and fruits grown in fungicide treated cocoa plantations communities pose health hazards for consumers.

\section{CONFLICT OF INTEREST}

The authors declare that they have no conflict of interest.

\section{REFERENCES}

Adeyeye, F., \& Balah, H. (2007). Fungicide-Derived Copper Content in Soil and Vegetation Component, Owena Cocoa (Theobroma Cacao L.) Plantations in Nigeria. Bangladesh J. Sci. Ind. Res., 41(3-4), 129-140.

Alloway, J. (1995). Soil Pollution and Land Contamination. In Pollution: Causes, Effects and Control. (Ed. Harrison, R.M.). Cambridge: The Royal Society of Chemistry, p. 318.

Arora, G., \& Musa, A. (2008). Organochlorine insecticides in the blood of occupationally people in Sudan. Bull. Environ. Contam. Toxicol., 16, 15-17.

Bempah, M., Dickson, N., \& Ormand, K. (2011). Distribution of fungicide - derived copper in soils, litter and vegetation of different aged stands of coffee (Coffee arabica L.) in Kenya. Plant and Soil, 77, 263-270.

Bolger, C., Chaussod, R., Leveque, J., Dousset, S., \& Andreux, F. (2000). The relationship between copper accumulated in vineyard calcareous soils and soil organic matter and iron. European Journal of Soil Science, 53, 663-669.

Bowers, K., Wiechula, D., \& Korus, I. (2001). Metal contamination of farming soils affected by industry. Environment International, 30, 159-165.

Claeys, U., Kuo, S., Heilman, A., \& Baker, S. (2011). Distribution and forms of Copper, Zinc, Cadmium, Iron, and manganese in soils near a Copper smelter. Soil Sci., 135,101-109.

Dudka G., \& Miller, B. (2009). Residues of organochlorine insecticides in some fishes and birds in the Gezira of Sudan. Pesticide Science, 7, 150-152.

Ekpo, F., Ukpong, E., \& Udoumoh, I. (2014). Bioaccumulations of Heavy Metals on Soil and Arable Crops Grown in Abandoned Peacock Paint Industry in Ikot Ekan, Etinan Local Government Area, Akwa Ibom State, Nigeria. Universal
Journal of Environmental Research and Technology, 4(1), 3945.

FEPA (1991). Guidelines and standards for Environmental Pollution Control in Nigeria. Federal Environmental Protection Agency (FEPA), Lagos, Nigeria.

George, C. (2006). Why farmers continue to use pesticides despite environmental, health and Sustainability costs. Ecological Economics, 39, 449-462.

Gutormsen, K., Sander, R., \& Korus, I. (1995). Metal contamination of farming soils affected by industry. Environment International, 30, 159-165.

Hayes, N. (2004). Assessing the impact of pesticides on the environment. Agric. Ecosystems Environ., 60, 81-96.

Hodgson, N. (2003). Long-Term Studies of Fungicide Concentrations in Greenhouses: Exposure Risks after Spraying in Greenhouses. J. Agric Food Chem., 44, 28852888.

Isong, R. (2007). Impact of Cocoa Research innovation on poverty alleviation in Nigeria. Inaugural Lecture of the Nigeria Academy of Arts and Science, p. 32.

Juraske, P., Badilla-Ohlbaum, R., Allen, H., \& Gustavo, E. (2001). Effect of soil copper content and pH on copper uptake of selected vegetables grown under controlled conditions. Environmental Toxicology and Chemistry, 21, 1736-1744.

Kabata-Pendias, A., \& Pendias, H. (1992). Trace Elements in Soils and Plants. $2^{\text {nd }}$ edition CRC Press Inc., Boca Raton, $\mathrm{p}$. 342

More, M., Giller, K., Witter, E., \& McGrath, P. (2003). Toxicity of heavy metals toMicroorganisms and microbial processes in agricultural soils: A review. Soil Biology and Biochemistry, 30, 1389-1414.

Nzegbule, E. (2007). Pollution distribution and effects in forest adjacent to smelters. Journal of Environmental Quality, 13, 377-382.

Smith, L. (2010). Effect of long-term application of copper on soil; and grape (Vitis vinfera). Canadian Journal of Soil Science, 74(3), 345-347.

Steel, R., \& Torrie, J. (1980). Principles and procedures of statistics- a biometrical approach, 3rdedition, McGraw-Hill Book Coy. NY, USA.

Tan, G., \& Tan, W. (1990). Additive inheritance of resistance to pot rot caused by Phytophthora palmivora in cocoa. Theor. Appl., Pp. 32-46.

Taylor, A. (2000). Organochlorine insecticides level s in human blood samples collected from residents in areas of limited and intensive insecticides use in the Sudan. M. Sc. Thesis, Faculty of Agriculture, University of Khartoum.

Ukpong, P. (2010). Assessment of heavy metals pollution in fungicide treated Cocoa plantations in Northern Cross River state, Nigeria. Journal of Applied Biosciences, 33, 2037-2046.

Wagner, J. (2003). Pollution distribution and effects in forest adjacent to smelters. Journal of Environmental Quality, Pp. 13 377-382.

Walter, M., Ansari, G., \& Mueller, J. (2005). Heavy metals in freshly deposited sediments of the Gomati River (a tributary of the Ganga River): Effects of human activities. Environmental Geology, 29, 247-252.

World Health Organization (WHO). (2001). Food additives and Contaminants, Joint FAO/WHO Standards Programme, Pp. 1-289. 